\title{
Control of Lesion Nematodes, Pratylenchus spp., in Grapevine Nursery Material by Immersion in Fenamiphos Solutions and Hot Water
}

\author{
J.T. Loubser \& G.F.J. Höppner \\ Viticultural and Oenological Research Institute, Private Bag X5026, 7600 Stellenbosch, Republic of South Africa. \\ Submitted for publication: October 1985 \\ Accepted for publication: November 1985 \\ Keywords: Pratylenchus, nematode control, grapevine nursery material
}

\begin{abstract}
Control of Pratylenchus spp. in dormant grapevine nursery material was attempted using fenamiphos solutions, and a hot-water treatment. Five months after treatment, the lesion nematodes were eradicated by all treatments. Although no visual phytotoxicity symptoms were recorded at any stage with any of the treatments tested, hot water significantly reduced plant growth of certain scion/rootstock combinations. Treatment with $0,1 \%$ (a.i.) fenamiphos solution for 30 minutes at $25^{\circ} \mathrm{C}$ is recommended.
\end{abstract}

Pratylenchus spp. are migratory endo-parasites which attack a wide variety of crops. As this nematode moves in and out of the roots of its host, it sometimes causes conspicuous lesions from which the descriptive name, i.e. root-lesion nematodes, is derived. Root-lesion nematodes have been shown to cause serious root damage of grapevines which can lead to stunting (Pinochet, Raski \& Goheen, 1976) or root invasion by secondary pathogens (Powell, 1971).

To date four species of root-lesion nematodes have been recorded in South African vineyards; viz. Pratylenchus penetrans, Pratylenchus vulnus, Pratylenchus minyus and Pratylenchus crenatus (Smith, 1982).

Pratylenchus spp. are widely distributed throughout the viticultural areas of South Africa (Smith, 1977) and growers are concerned about establishing new vineyards with infested propagation material. It is also a legal requirement that nursery material must be free from these nematodes.

Control of nematodes in plants by hot-water treatment has become a widely used practice (Lear \& Lider, 1959; Raski, Hart \& Kasimatis, 1973). This technique can also be applied to control Pratylenchus spp. on grapevine (Lear, 1966) as well as other plants (Way, 1973; Towson \& Lear, 1982).

However, since this method has become a fairly general practice in South Africa for the control of Phytophthora cinnamomi on grapevine propagation material (Von Broembsen \& Marais, 1978), several reports of physiological damage and dieback have been received from growers.

Chemical treatment of roots infested with parasitic nematodes has received special attention since the introduction of systemic nematicides (Suatmadji, 1982). The method has been tested with varying degrees of success on different crops and several nematode species (Dale, 1973; Milne, 1973; Bolander \& Santo, 1977; Coates-Beckford, 1977; Grandison, 1983). To our knowledge no attempt has been made to eradicate Pratylenchus spp. from grapevines with these chemicals and a trial was therefore conducted on dormant grapevine material. Special attention was given to possible phytotoxicity of the treatments to different grapevine scion/rootstock combinations.

\section{MATERIAL AND METHODS}

\section{Plant Material:}

The experiment was conducted during August 1984 with one year old, dormant rooted vines consisting of the following scion/rootstock combinations:
A. Dan-ben-Hannah/Ramsey
B. Dan-ben-Hannah/99 Richter
C. Bien Donné/99 Richter
D. Cabernet Sauvignon/101-14 Mgt
E. Colombar/Ramsey
F. Muscat d'Alexandrie/Jacquez
G. Colombar/99 Richter

\section{Treatments:}

The following treatments were applied to all scion/ rootstock combinations:

1. Fenamiphos (Nemacur $40 \%$ ec) solution $(0,1 \%$ a.i.) at $15^{\circ} \mathrm{C}$ for $60 \mathrm{~min}$.

2. Fenamiphos (Nemacur $40 \%$ ec) solution $(0,2 \%$ a.i.) at $15^{\circ} \mathrm{C}$ for $60 \mathrm{~min}$.

3. Fenamiphos (Nemacur $40 \%$ ec) solution $(0,1 \%$ a.i.) at $25^{\circ} \mathrm{C}$ for $30 \mathrm{~min}$

4. Fenamiphos (Nemacur $40 \%$ ec) solution $(0,2 \%$ a.i.) at $25^{\circ} \mathrm{C}$ for $30 \mathrm{~min}$

5. Hot-water at $50^{\circ} \mathrm{C}$ for 15 minutes.

6. Untreated control.

Before treatment vines were all pruned to two buds, roots cut back to a length of $100 \mathrm{~mm}$, and the total mass of each plant determined. The roots thus removed were analysed for nematode infestation by a maceration sieving technique as described below. Scion/rootstock combinations A-F were found to be free from parasitic nematodes, while scion/rootstock combination $\mathrm{G}$ was infested by Pratylenchus spp.

Plant roots were immersed in hot water or in the fenamiphos solutions for the required time and immediately thereafter rinsed in cold water. Plants were individually planted in pots containing a sterilized $\left(120^{\circ} \mathrm{C}\right.$, $15 \mathrm{~min}$.) sand/peat moss potting mixture and were grown under shaded conditions in a plastic tunnel with 
temperatures ranging between $19^{\circ} \mathrm{C}$ and $28^{\circ} \mathrm{C}$.

A. Nematode control:

Nematode control was evaluated three and five months after treatment on the Colombar/99 Richter combination $(\mathrm{G})$ found to be infested with Pratylenchus spp. before treatment. Seven replicates consisting of four vines each were evaluated each time by using a composite root sample for analysis. The number of nematodes were determined by the following maceration sieving technique:

Roots were cut into lengths of $20 \mathrm{~mm}$ or less and a randomly picked sample of $50 \mathrm{~g}$ placed in $200 \mathrm{ml}$ water and macerated for 10 seconds in a blender. The resulting suspension was passed through a series of sieves $(125 \mu, 90 \mu$ and $38 \mu)$ and the root debri washed with a spray of water. The nematodes were collected from the bottom $(38 \mu)$ sieve by washing it into a beaker and allowed to settle under gravitation for 30 minutes. Water was syphoned from the beaker to obtain a $50 \mathrm{ml}$ working suspension and nematode counts were made from this using a $2 \mathrm{ml}$ capacity counting chamber.

\section{B. Phytotoxicity evaluations:}

A total of seven plants per scion/rootstock combination (A-F) were used for assessment of possible phytotoxicity. Phytotoxicity of treatments was regularly assessed for visual symptoms during the growing period and after five months all plants were removed and phytotoxicity assessed by determining plant mass increase, total root mass, total shoot mass and total shoot length. Data was subjected to a three way analyses of variance.

\section{RESULTS AND DISCUSSION}

\section{A. Nematode control:}

The number of Pratylenchus nematodes found in the roots, three and five months after fenamiphos and hot water treatments, is shown in Table 1.

TABLE 1. Effect of fenamiphos solutions and hot-water treatments on Pratylenchus numbers in Colombar/99 Richter roots.

\begin{tabular}{|c|c|c|}
\hline \multirow{2}{*}{ Treatment } & \multicolumn{2}{|c|}{$\begin{array}{l}\text { Number of Pratylenchus } / 50 \mathrm{~g} \\
\text { of roots }\end{array}$} \\
\hline & After 3 months & After 5 months \\
\hline $\begin{array}{l}\text { 1. Fenamiphos }(0,1 \% \text { a.i. }) \\
\text { at } 15^{\circ} \mathrm{C} \text { for } 60 \mathrm{~min} \text {. }\end{array}$ & 85,71 a & 0 \\
\hline $\begin{array}{l}\text { 2. Fenamiphos }(0,2 \% \text { a.i. }) \\
\text { at } 15^{\circ} \mathrm{C} \text { for } 60 \mathrm{~min} \text {. }\end{array}$ & $14,29 \mathrm{a}$ & 0 \\
\hline $\begin{array}{l}\text { 3. Fenamiphos }(0.1 \% \text { a.i. }) \\
\text { at } 25^{\circ} \mathrm{C} \text { for } 30 \mathrm{~min} \text {. }\end{array}$ & $71,43 \mathrm{a}$ & 0 \\
\hline $\begin{array}{l}\text { 4. Fenamiphos }(0,2 \% \text { a.i. }) \\
\text { at } 25^{\circ} \mathrm{C} \text { for } 30 \mathrm{~min} \text {. }\end{array}$ & $62,86 \mathrm{a}$ & 0 \\
\hline 5. Hot-water at $50^{\circ} \mathrm{C}$ for $15 \mathrm{~min}$. & $40,00 \mathrm{a}$ & 0 \\
\hline 6. Control & $88,57 \mathrm{a}$ & 464,29 \\
\hline
\end{tabular}

Three months after treatment Pratylenchus individuals were found in all treated vines and although differences occured between treatments, this was not significant. However, nematodes extracted from treated vines were inactive and appeared to be dead.

After five months no Pratylenchus could be found on any of the treated vines, whereas numbers in the roots of untreated vines increased substantially. It was con- cluded that the nematodes found in the roots of treated vines during the initial evaluations, were in fact dead or non-infective. One composite soil sample from treated vines was analysed at this stage for the presence of Pratylenchus, but no nematodes were extracted.

This proves that a systemic nematicide such as fenamiphos can be used with success to eradicate Pratylenchus spp. from grapevine nursery material. According to Suatmadji (1982), Meloidogyne javanica will also be eradicated during such a treatment and this method can therefore serve a dual purpose with a minimum of effort and at a low cost.

\section{B. Phytotoxicity evaluations:}

The effect of treatments on plant mass increase, root mass as well as shoot mass and shoot length, is shown in Table 2 .

TABLE 2. Effect of fenamiphos and hot water on growth of grapevine nursery material.

\begin{tabular}{l|c|c|c|c}
\hline \multicolumn{1}{c|}{ Treatment } & $\begin{array}{c}\text { Plant mass } \\
\text { increase } \\
(\mathrm{g})\end{array}$ & $\begin{array}{c}\text { Root } \\
\text { mass } \\
(\mathrm{g})\end{array}$ & $\begin{array}{c}\text { Shoot } \\
\text { mass } \\
(\mathrm{g})\end{array}$ & $\begin{array}{c}\text { Shoot } \\
\text { length } \\
(\mathrm{mm})\end{array}$ \\
\hline $\begin{array}{l}\text { 1. Fenamiphos }(0.1 \% \text { a.i. }) \\
\text { at } 15^{\circ} \mathrm{C} \text { for } 60 \mathrm{~min} .\end{array}$ & $77.67 \mathrm{bc}$ & $36.45 \mathrm{ab}$ & $47.05 \mathrm{a}$ & $1075.7 \mathrm{ac}$ \\
$\begin{array}{l}\text { 2.Fenamiphos }(0.2 \% \text { a.i. }) \\
\text { at } 15^{\circ} \mathrm{C} \text { for } 60 \mathrm{~min} .\end{array}$ & $64.05 \mathrm{ab}$ & $39.57 \mathrm{bc}$ & $30.48 \mathrm{~b}$ & $945.0 \mathrm{a}$ \\
$\begin{array}{l}\text { 3. Fenamiphos }(0.1 \% \text { a.i. }) \\
\text { at } 25^{\circ} \mathrm{C} \text { for } 30 \mathrm{~min} .\end{array}$ & $78.29 \mathrm{c}$ & $42.07 \mathrm{c}$ & $42.50 \mathrm{a}$ & $1277.1 \mathrm{~b}$ \\
$\begin{array}{l}\text { 4.Fenamiphos }(0.2 \% \text { a.i. }) \\
\text { at } 25^{\circ} \mathrm{C} \text { for } 30 \mathrm{~min} .\end{array}$ & $75.57 \mathrm{bc}$ & $43.05 \mathrm{c}$ & $38.57 \mathrm{ac}$ & $1250.5 \mathrm{bc}$ \\
$\begin{array}{l}\text { 5.Hot-water at } 50^{\circ} \mathrm{C} \\
\text { at } 15 \mathrm{~min} .\end{array}$ & $56.83 \mathrm{a}$ & $32.50 \mathrm{a}$ & $29.67 \mathrm{~b}$ & $1022.6 \mathrm{ac}$ \\
6.Control & $67.98 \mathrm{bc}$ & $39.93 \mathrm{bc}$ & $35.29 \mathrm{bc}$ & $134.5 \mathrm{ab}$ \\
\hline
\end{tabular}

Plant mass increase as well as root mass of the hotwater treated vines are significantly lower than those of the control. Although no visual signs of phytotoxicity were observed at any stage during this experiment, hot water evidently affected plant growth to a lesser extent. No other treatment resulted in statistically lower masses or shoot lengths than the control.

Significant differences occured between the fenamiphos treatments and a $0,1 \%$ (a.i.) solution at $25^{\circ} \mathrm{C}$ for 30 minutes (treatment 3 ) proved better than a $0,1 \%$ (a.i.) solution at $15^{\circ} \mathrm{C}$ for 60 minutes (treatment 1 ) in terms of root mass and shoot length. Equally a $0,2 \%$ (a.i.) fenamiphos solution at $25^{\circ} \mathrm{C}$ for 30 minutes (treatment 4) gave significantly better results than a $0,2 \%$ (a.i.) solution at $15^{\circ} \mathrm{C}$ for 60 minutes (treatment 2) in terms of shoot mass and shoot length. No significant differences were recorded between treatments 3 and 4 . These results imply that the longer treatment time, rather than the higher dosage, may have a marginal negative effect on plant growth.

In the case of fenamiphos treatments no differences were found between different scion/rootstock combinations. However, results of hot-water treatments presented in Table 3 show that different scion/rootstock combinations react differently to hot-water treatment and this may well account for the negative reports occasionally received from vine growers. 
TABLE 3. The effect of hot-water treatment on growth of different scion/rootstock combinations.

\begin{tabular}{l|l|l|l|l|c|c|c}
\hline & & $\begin{array}{l}\text { A. Dan-ben } \\
\text { Hannah on } \\
\text { Ramsey }\end{array}$ & $\begin{array}{l}\text { B. Dan-ben } \\
\text { Hannah on 99 } \\
\text { Richter }\end{array}$ & $\begin{array}{l}\text { C. Bien Donné } \\
\text { on 99 } \\
\text { Richter }\end{array}$ & $\begin{array}{l}\text { D. Cabernet } \\
\text { Sauvignon on } \\
101-14 \text { Mgt }\end{array}$ & $\begin{array}{l}\text { E. Colombar } \\
\text { on Ramsey }\end{array}$ & $\begin{array}{l}\text { F. Muscat d } \\
\text { Alexandrie on } \\
\text { Jacquez }\end{array}$ \\
\hline \multirow{2}{*}{$\begin{array}{l}\text { Plant mass } \\
\text { increase }\end{array}$} & Treated & $46 \mathrm{a}$ & $37 \mathrm{a}$ & $102 \mathrm{a}$ & $72 \mathrm{a}$ & $25 \mathrm{a}$ & $58 \mathrm{a}$ \\
\cline { 2 - 9 } & Untreated & $62 \mathrm{a}$ & $77 \mathrm{~b}$ & $64 \mathrm{a}$ & $81 \mathrm{a}$ & $58 \mathrm{~b}$ & $73 \mathrm{a}$ \\
\hline \multirow{2}{*}{ Root mass } & Treated & $21 \mathrm{a}$ & $26 \mathrm{a}$ & $70 \mathrm{a}$ & $39 \mathrm{a}$ & $9 \mathrm{a}$ & $31 \mathrm{a}$ \\
\cline { 2 - 8 } & Untreated & $41 \mathrm{a}$ & $46 \mathrm{a}$ & $35 \mathrm{a}$ & $37 \mathrm{a}$ & $31 \mathrm{~b}$ & $44 \mathrm{a}$ \\
\hline
\end{tabular}

Scion/rootstock B (Dan-ben-Hannah/99 Richter) yielded a significantly lower plant mass increase, while scion/rootstock E (Colombar/Ramsey) showed highly significant lower plant mass increase as well as root mass than their untreated controls. Although the effect of hot-water treatment could not be detected visually, the reduction in plant and root growth measured for these scion/rootstock combinations, especially Colombar/Ramsey, imply that hot-water treatment may sometimes be hazardous in practice.

\section{CONCLUSIONS}

Treatment of grapevine nursery material with fenamiphos or hot water is effective in eradicating Pratylenchus spp. All treatments successfully eradicate this endo-parasite from roots, therefore infested nursery material can be treated before planting.

It is recommended that preference should be given to treatment with a $0,1 \%$ (a.i.) solution of fenamiphos for 30 minutes at c.a. $25^{\circ} \mathrm{C}$. Because plant growth of certain scion/rootstock combinations was adversely affected by hot-water treatment, this method cannot be generally recommended for the eradication of Pratylenchus spp. from grapevine nursery material.

\section{REFERENCES}

BOLANDER, W.J. \& SANTO, G.S., 1977. Elimination of Meloidogyne hapla in potato seed-pieces with phenamiphos dip treatment. Pl. Dis. Reptr 61, 743-745.

COATES-BECKFORD, P.L., 1977. Comparison of various treatments for the control of Pratylenchus coffeae in yams. Nematropica 7, 20-26.
DALE, P.S., 1973. Elimination of root-knot nematodes from roses by bareroot dips. N.Z. Journal of Experimental Agriculture 1, 121-122.

LEAR, B., 1966. Hot-water treatment of grapevine rootings for eradication of a root-lesion nematode, Pratylenchus vulnus. Pl. Dis. Reptr 50, 858-859.

LEAR, B. \& LIDER, L.A.. 1959. Eradication of root-knot nematodes from grapevine rootings by hot water. Pl. Dis. Reptr 43, 314-317.

MILNE, D.L., 1973. Nematicidal dips for the protection of pineapple plants. Citrus \& Subtr. Fruit Journal 473, 8-10.

PINOCHET, J., RASKI, D.J. \& GOHEEN, A.C. 1976. Effects of Pratylenchus vulnus and Xiphinema index singly and combined on vine growth of Vitis vinifera. J. Nematol 8, 330-335.

POWELL, N.T., 1971. Interaction of plant parasitic nematodes with other disease-causing agents. In Plant Parasitic Nematodes Vol. II, 119-136. Ed. Zuckerman, Mai \& Rohde. Acad. Press, New York and London.

RASKI, D.J., HART, W.H. \& KASIMATIS, A.N., 1973. Nematodes and their control in vinevards. Circ. Calif. Agric. Exp. Stn No. 533. Revised.

SMITH, P.C., 1977. Distribution of plant-parasitic nematodes in vineyards in the Western Cape Province. Phytophylactica 9, 27-28.

SMITH, P.C., 1982. Nematode pests of grapevines. In Nematology in Southern Africa, 88-95. Ed. Keetch \& Heyns. Scientific Bulletin no. 400, Department of Agriculture and Fisheries, Republic of South Africa, Government Printer, Pretoria.

SUATMADJI, R.W., 1982. Control of rootknot nematodes. Meloidogyne javanica, in rooted stocks of grapevine, Vitis vinifera, by immersion in nematicide solutions at different temperatures and in hot water. Nematol. Medit. 10, 119-125.

TOWSON, A.J. \& LEAR, B., 1982. Control of nematodes in rose plants by hot-water treatments preceded by heat hardening. $\mathrm{Ne}$ matologica 28, 339-353.

VON BROEMBSEN, SHARON \& MARAIS, P.G., 1978. Eradication of Phytophthora cinnamomi from grapevine by hot-water treatment. Phytophylactica 13, 25-27.

WAY, J.J., 1973. Phytothermotherapy for nematode control. Nematol. Soc. s. A. Newsletter 4, 4. 